\title{
Abstinence from Premarital Sex: A Precursor to Quality Relationship and Marital Stability in Subsequent Marriage in Nigerian Society
}

\author{
Moses O. Ogunsola ${ }^{1}$ \\ ${ }^{1}$ Department of Guidance and Counselling, University of Ibadan, Ibadan. Nigeria \\ Correspondence: Moses O. Ogunsola, Department of Guidance and Counselling, University of Ibadan, Ibadan, \\ Nigeria. Tel: 234-803-402-7590. E-mail: blestson@yahoo.com
}

Received: February 1, 2012

Accepted: April 26, 2012 Published: June 1, 2012

doi:10.5539/ijps.v4n2p228

URL: http://dx.doi.org/10.5539/ijps.v4n2p228

\begin{abstract}
The last half of the 20th century has witnessed substantial changes in the practice of premarital partnership among the youths and unmarried adults. The growing trend in premarital behavioural pattern of today exposes teenagers to living in the world of great sexual exploration and indulgence. This could negatively impact future marital quality and marital stability. This study examined the influence of premarital sex among 3,824 married people where 1931 (50.5\%) were males and 1893 (49.5\%) were female. The study showed that the respondents who engaged in premarital romantic activities and coitus did not experience the same quality marital relationship and stability as the married people who abstained from premarital sexual activities. Premarital sexual activities have potentially damaging effect on subsequent marriage relationships. Sexual abstinence among the youth before marriage could promote healthy marriage relationship in the future.
\end{abstract}

Keywords: marriage, premarital romance, premarital sex, marital stability, marital quality

\section{Introduction}

The last half of the 20th century has witnessed substantial changes in the practice of premarital partnership among the youths due, in part, to the influx of the western culture in the continent of Africa (Ikpe 2004; Akinwale 2009). Ikpe (2004) highlighted western education and urbanization as factors that influence pre-marital sex in Nigeria. In recent times, premarital sex is being considered as an acceptable and harmless behaviour by a good number of people, especially among the non-married, in most societies and cultures of the world. Akinwale (2009) reported a link between the growth of premarital sexual activities in Nigeria and the adoption of western culture of sexuality as well as the relegation of traditional idioms of sexuality in the country. The youth age marks a thrilling game of choice and dating, played with great zest, that older people often watch with wonder; speculating if the rest of life will be as exhilarating as the romantic "teen years" (Clarke, 1947). Young people therefore desire to maximize their freedom of choice at this period with no or little parental influence on decision-making processes. This is because youngsters crave for identity and independence. Consequently, young adults endeavor to set their own goals and establish divergent values to that of their parents or the society where they live (Erikson, 1968). The matter of what should be the pattern of premarital behaviour among them is hence determined, to a large extent, by the individual youth in our fast growing modern society.

The ever growing change in premarital behavioural patterns of youngsters continually exposes today's teenagers to be living in the world of great explorations (Adebayo, Udegbe \& Sunmola, 2006). Premarital activities of today's youth that give liberty to close intimacy of unhealthy romantic explorations during dating in contrast to the traditional approach which involved parents in premarital advances are observed to be full of sexual risks (Inyang, 2007; Akinawo and Owoniki, 2007). It has also been noticed that most behavioural responses of young people habitually revolve around sexual activities, the practice that Inyang (2007) viewed as the usual aftermath of intimacy in emotion-laden romantic relationships. Since one thing will always lead to another, engagement in the pleasure of romantic intimacy, more often than not, usually end up in sexual intercourse between the youngsters. And because sexual relations proffer the most passionate pleasure, young people are not usually emotionally balanced to control the urge for the fun. This seems to explain the insatiable feelings in youngsters to always desire intimate relationship with the opposite sex; the practice that often sustains the inherent danger of unhealthy romantic activities. Premarital behaviours of Nigerian youngsters, therefore, in this trend are noticed to pose major threats to life and the future of the country as teenagers engage in reckless sexual risks which World Health Organization [WHO] (2001) affirm to be the characteristic feature of the adolescent stage among 
young people. Premarital sex is associated with the phenomenon of teenage and unintended pregnancies, abortion, the spread of STIs and HIV (Alo \& Akinde, 2010).

Many reasons are often postulated by the youngsters who engage in reckless romantic and sexual explorations to justify their sexual behaviour. For instance, Rena (2006) observed that people believe premarital sex is okay because premarital sex is all around us; peer pressure and society says premarital sex is okay; schools say it is acceptable as long as you have "safe sex"; so far it is pleasurable and acceptable, so why wait until marriage? In today's society, it appears much is all about romance and sex on the TV, internet, radio, VCDs, CDs, cell phones, video games, movies, comics and in music. More often than not, people who engage in romantic explorations and sexual relationship outside of marriage usually do not end up in marrying each other. Few people, however, might possibly consider marriage because they had sex or pregnancy before the actual marriage. Rena (2006) hence considers the significance of moral justification that requires self-control in avoiding premarital sex which would eventually make the couples to be faithful to one another after marriage. As a matter of facts, an individual that cannot control his/her sexual passions in premarital days may end up in promiscuity and adultery after marriage. Although premarital sex is often viewed to be a springboard to marital happiness by intending couples, the reality of this assumption has been contended in research studies. For instance, Rena (2006) asserts that a major problem of premarital sex is that it often leads to divorce. It is on the premise of the foregoing that this study was carried out to examine the effects of premarital romantic and sexual relationships on the quality of relationship and marital stability in Nigerian society.

\subsection{Hypotheses}

Two null hypotheses were put forward in this study namely:

1) Premarital romantic activities do not significantly affect marital stability and the quality of marital relationship of the married people

2) Premarital sex does not significantly affect marital stability and the quality of marital relationship of the married people

\section{Methodology}

The study adopted a survey research design using an ex-post facto type. This design usually collects data after the event or phenomenon under investigation has taken place. In the course of this study, the researcher had no control over the variables of interest and could not manipulate them.

\subsection{Population}

The target population for this study was the married people in Southwest Nigeria. Southwest Nigeria comprises six states namely Lagos, Ogun, Oyo, Ondo, Osun and Ekiti.

\subsection{Sample and Sampling Procedure}

The participants in this study were randomly selected from Southwest Nigeria using multistage random sampling technique. In the process, three states were randomly selected from which six senatorial districts (two from each state) were chosen for the study. Furthermore, five Local Government Councils were selected from each of the six senatorial districts to make up thirty Local Government Councils used for this study. Thus, the author was able to cover 30 out of 55 Local Government Councils (54.55\%) within the six Senatorial Districts that made up the sample population. In all, 5,400 questionnaires aimed at collecting data from 2,700 males and 2,700 females were distributed to the respondents. Of these, 3,824 questionnaires were retrieved for data analysis. Table 1 showed the summary characteristics of the population used for this study. Out of the total population surveyed, $48 \%$ were between 24 to 40 years and $87 \%$ were ages 24 to 65 years. About $84 \%$ had some form of post secondary education and $95 \%$ were currently in a form of marital relationship.

\subsection{Instrumentation}

Two validated research instruments were used to collect data from the respondents. The instruments are:

1) Marital relationship quality was measured by using 50 items Marital Relationship Quality Inventory (MRQI). MRQI consists of six sections with validated sub-scale sections B to F. Section A was designed to collect data on demographic characteristics of the respondents while Sections B, C, D, and F are sub-scales that gathered data on marital relationship quality indices. MRQI has an internal consistency reliability of 0.97 .

2) Marital stability of the married individuals was measured using Marital Stability Assessment Scale (MSAS). The instrument consists of 22 items in Likert-format self-reporting scale. It has internal consistency reliability 0.86 . 


\subsection{Data Analysis}

Data was analysed by the use of student t-test to establish the mean differences of the independent variables in the study.

\section{Result}

The result shown in Table 2 showed that the effect of premarital romance on the quality of marital relationship is significant $(P<0.05)$. The significant level of significance of premarital romance the quality of marital relationship suggested that the null hypothesis set forth could be rejected. Married individuals who did not engage in romantic explorations before marriage experienced greater quality of marital relationship than those who did.

Table 1. Demographic characteristics of the study

\begin{tabular}{|c|c|c|c|c|c|}
\hline $\begin{array}{l}\text { Age } \\
\text { (Years) }\end{array}$ & Frequency $(\mathrm{N})$ & $\begin{array}{l}\text { Percentage } \\
(\%)\end{array}$ & Educational Status & $\begin{array}{l}\text { Frequency } \\
\text { (N) }\end{array}$ & $\begin{array}{l}\text { Percentage } \\
(\%)\end{array}$ \\
\hline Below 24 & 216 & $5.6 \%$ & Degree/HND \& above & 1966 & $51.4 \%$ \\
\hline $24-40$ & 1817 & $47.5 \%$ & NCE/OND/Diploma & 1261 & $33.0 \%$ \\
\hline $41-65$ & 1492 & $39.0 \%$ & $\begin{array}{l}\text { Grade II/Secondary School } \\
\text { Certificate }\end{array}$ & 308 & $8.1 \%$ \\
\hline above 65 & 149 & $3.9 \%$ & Primary School \& Below & 289 & $7.6 \%$ \\
\hline Missing & 150 & $3.9 \%$ & & & \\
\hline Total & 3824 & $100.0 \%$ & Total & 3824 & $100.0 \%$ \\
\hline
\end{tabular}

HND means Higher National Diploma

NCE means National Certificate in Education

OND means Ordinary National Diploma

Table 2 also showed the effect of premarital romantic activities on marital stability. There was significant effect $(P<0.05)$ of premarital romantic activities on marital stability of the respondents. The married people who indicated that they were not involved in romantic explorations before marriage experienced greater marital stability than those who did. This suggested that premarital romantic activities have potentially damaging impact on the stability of the marriage. The result shown in Table 3 indicated a significant effect $(P<0.05)$ of premarital sex on quality of marital relationship. Married individuals who did not have coitus before marriage experienced greater quality of marital relationship than those that did. Table 3 also showed the effect of premarital sex on marital stability. There was significant effect of premarital sex on marital stability of the respondents. The married people who indicated that they did not have coitus before marriage experience greater marital stability than those that did. This suggested that premarital sex has potentially damaging impact on the stability of the marriage.

Table 2. Effects of premarital romantic activities on quality of marital relationship and marital stability

\begin{tabular}{|c|c|c|c|c|c|c|}
\hline Premarital Sex & $\mathrm{N}$ & Mean & SD & $\mathrm{t}$ & df & $\mathrm{P}_{\text {value }}$ \\
\hline \multicolumn{7}{|l|}{ Quality of marital relationship } \\
\hline No Romantic Activities before Marriage & 3105 & 142.84 & 22.44 & \multirow{2}{*}{2.22} & \multirow{2}{*}{3625} & \multirow{2}{*}{0.026} \\
\hline Romantic Activities before Marriage & 522 & 140.50 & 20.65 & & & \\
\hline \multicolumn{7}{|l|}{ Marital Stability } \\
\hline No Romantic Activities before Marriage & 3286 & 82.65 & 19.70 & \multirow{2}{*}{2.38} & \multirow{2}{*}{3622} & \multirow{2}{*}{0.017} \\
\hline Romantic Activities before Marriage & 538 & 80.47 & 19.46 & & & \\
\hline
\end{tabular}


Table 3. Effects of premarital sex on quality of marital relationship and marital stability

\begin{tabular}{lllllll}
\hline Premarital Sex & $\mathrm{N}$ & Mean & $\mathrm{SD}$ & $\mathrm{t}$ & $\mathrm{df}$ & $\mathrm{P}_{\text {value }}$ \\
\hline Quality of Marital relationship & & & & & & \\
No Coitus before Marriage & 3248 & 142.84 & 21.96 & & & \\
Coitus before Marriage & 379 & 139.60 & 23.99 & 2.69 & 3625 & 0.007 \\
Marital Stability & & & & & & \\
No Coitus before Marriage & 3432 & 82.56 & 19.57 & & & \\
Coitus before Marriage & 392 & 80.46 & 20.59 & 2.00 & 3822 & 0.046 \\
\hline
\end{tabular}

\section{Discussion}

The findings from this study showed significant effects of premarital romantic explorations on the quality of conjugal relationships and marital stability in subsequent marriages of the respondents. This result averred that the individuals who engaged in premarital romantic activities experienced lower quality of marital relationship and marital stability than their counterparts that did not. The study invalidated the common postulation among the young people that intimacy in romantic relationships before marriage could promote companionship and compatibility essential for enhancing the quality relationship in subsequent marriage. Instead, premarital romantic engagements of today's youths that are constantly reinforced by pornography, blue-films, nudity and sex-induced music make them more vulnerable to sexual passions and its dangerous consequences.

This study also showed that there was significant effect of premarital sex on the quality of marital relationship and marital stability with couples that did not have premarital sex having greater quality of marital relationship and marital stability than couples that engaged in premarital sex. Booth and Johnson (1988) and Cohan and Kleinbaum (2002) reported that couples who engaged in premarital sex under cohabitation arrangement before marriage tend to show lower levels of relationship satisfaction than couples who did not. Teachman (2003) reported that women who have more than one intimate premarital relationship have an increased risk of marital dissolution. While there might be some direct link between premarital sex and marital quality and stability, the significant effect of premarital sex on the relationship quality and marital stability might be due to some indirect consequences of premarital sex. Teachman (2003) demonstrated that the link between premarital sex and marriage stability was not direct.

Premarital sex gives room for sexual comparison since the couple must have experience sexual relationship with one or more individuals before the marriage. This could lead to a sense of dissatisfaction which, in turn, could affect the quality of the relationship between the couple. Premarital sex could also cause a sense of guilt in one or the two marriage partners which could negatively impact the quality of the marital relationship. Alo (2008) reported that public opinion polls had consistently shown that premarital sex is wrong. Traditionally in Nigeria, young girls are not expected to engage in premarital sex and sex within a marriage relationship between adult males and females is regarded to be sacred (Alo, 2008; Alo and Akinde, 2010). So, premarital sexual activity could result in a feeling of guilt for not keeping the sacredness of sex within the marriage relationship. This could negatively impact the couple's behavior and, hence, the quality of their marriages and marital stability.

Romantic explorations and sex before marriage have also been associated with several other problems such as abortions, teenage mothers and sexually transmitted infections (Aaron, 2006; Finer, 2007; Inyang, 2007) which could negatively impact the quality of marital relationship later in subsequent marriages. A survey conducted at Alan Guttmacher Institute showed that four out of every five abortion at the institute were undergone by those who were not married (Henshaw and Kost, 1996). Famuyide and Olunlade, (2001) reported that two out of every five teenage girls in secondary schools in Nigeria have had at least one pregnancy, and $60 \%$ of teenage patients show up in hospitals to complain about abortion complications.

In an effort to trace these major threats of premarital coitus to human life in Nigeria, Akinawo and Owanikin (2007) observed that accidents, malaria and HIV/AIDS are the three major killers with HIV/AIDS being the worst in Nigeria. Young adults, because they cannot actually comprehend or control fully the extent of their exposure to premarital romantic and sexual behaviours, become more vulnerable to this killer disease. This is of particular concern because of the prevalence of unprotected premarital sexual activity among young people in Nigeria which often result in early marriage and/or child bearing (Oloko and Omoboye, 1993; Famuyide and Olunlade, 2001). The vulnerability of the teenage girls above the males to premarital sexual abuse and to 
contacting HIV/AIDS, therefore, pose serious danger to the health prospects of young ladies. This was evident in the report of National Population Commission (2000) that teenage mothers had been found to be more likely to suffer from serious complications during delivery, resulting in higher morbidity and mortality for both mother and infants than the older women. Premarital activities of young adults, therefore, call for serious concern because they are the future generation of Nigeria. The psychosocial experiences of premarital days may eventually have severe implications on their adult life. Imagine for a moment, a world without premarital sex, there would be less sexually transmitted disease (STDs), there would be no unwed mothers, and there would be less unwanted pregnancies and abortion (Alo \& Akinde, 2010).

Premarital sex could also result in lack of openness in marriage union when a party is not willing to expose past sexual activities or is afraid of the partner getting to know about his or her past from other sources. The persistence sense of fear of the truth coming into light could affect the quality of a couple's relationship in marriage. In an article "10 things you must know before you say 'I do", in Ebony magazine (2000), the author asserted that marriage partners must seek to know about their partner's marital history as well as past sexual involvement. The author also asserted that finding out about the past could reduce the divorce statistics. While the truth about these is intentionally kept secret before marriage, finding the truth after marriage union could destroy trust within the marriage union.

Another problem that is associated with illicit premarital romantic sexual behaviours that could have indirect effect on the quality of marital relationship is the occurrence of unwanted pregnancy that often truncates the educational careers of young girls and cause inadequate preparation for future marriage life. Pregnant teenagers in Nigerian environment have a relatively low level of education, low socioeconomic status and socio-psychological immaturity (Ogunniyi, Dare, Makinde, Ogunniyi \& Ariyo, 1991; Okpani, Ikimalo, John \& Briggs, 1995; Adekanle, Adeyemi \& Odu, 2008). Lewis and Spanier (1979) reported that although absolute socio-economic circumstances might be less important in predicting marital quality than expectations and perceptions of adequacy satisfaction with lifestyle, job and socio-economic status leads to greater levels of marital satisfaction. Conger et al. (1990) reported negative but indirect effect economic strain on marital quality through promotion of negative behaviours and curtailment of positive behaviours. The effects of economic conditions might therefore operate through marital interaction factors such as tension and conflict and the effects would depend on coping resources and social support (Voydanoff, 1990).

Couples who engaged in premarital sex had been shown to be more prone to marital infidelity. For example, Treas and Giesen (2000) found positive correlation between marital infidelity and unwholesome premarital behavioural experiences in both men and women. White et al., (2000) also reported that the number of premarital partners was significantly correlated with extramarital intercourse after marriage. Ahlburg, Jensen \& Perez (1997) in a study conducted in Philipines reported that men who engaged in premarital sex are more likely to engage in sex outside marriage. Vondey (2010) stated that extra-marital sex is marriage's greatest enemy. Amato and Hohmann-Marriott (2007) reported that marital happiness declined after an incident of extramarital sex and that extramarital sex predicted divorce even when earlier levels of marital quality was held constant.

\section{Conclusion}

The result of the analysis in this study indicates that premarital romantic and sexual relationships have adverse effects on quality of marital relationship and stability of the married people in Southwest Nigeria. Consequently, the married people who did not engage in romantic and sexual explorations before marriage experienced better quality of marital relationship and marital stability than those who had sex before marriage. Premarital romance and sex hence exerted negative effects on the needed quality and stable relationship virtues instead of promoting harmonious relationship among the couples. This study, therefore, calls for necessary empowerment of the youngsters, especially the female teenagers, through proper sex education to avoid the harmful consequences of premarital behaviors that often lead to sexual activities. It is essential that decisive steps be taken to properly inform the young adults about the obstructive outcomes of premarital behaviors such as romantic intimacy and sexual relationships to avoid its negative consequences in their future marriages. Comprehensive sex education will enable Nigerian youths to make informed decisions that would checkmate the possible consequences of premarital sexual behavior in the future. While different factors that could indirectly account for the significant correlation between premarital sexual behavior and marital satisfaction and stability were identified, further study is required to evaluate the dominant factors under Nigeria system.

\section{References}

Aaron, N. G. (2006). Premarital sex: whose burden? Retrieved from http://www.singaporeangle.com

Adebayo, D. O., Udegbe, I. B., \& Sunmola, A. M. (2006). Gender, internet use and sexual behaviour orientation 
among young $\quad$ Nigerians. Cyber Psychol. Behaviour, 9(6), 742-752. http://dx.doi.org/10.1089/cpb.2006.9.742

Adekanle, D. A., Adeyemi, A. S., \& Odu, O. O. (2008). Teenage and non-teenage pregnant women in southwestern Nigeria: a descriptive study. Calicut Medical Journal, 6(3), 5.

Ahlburg, D. A., Jensen, E. R., \& Perez, A. E. (1997). Determinants of extramarital sex in the Philippines. Health Transition Review, Supplement to Volume 7, 467-479.

Akinawo, E. O., \& Owonikin, I. O. (2007). Knowledge of HIV/AIDS fear and sexual risk behaviours among selected school adolescents in Akure. In Nwazuoke et al. (Eds.), Education for Social Transformation (pp. 361-374). Ibadan: University Press.

Akinwale, A. A. (2009). Manifestation of human sexuality and its relevance to secondary schools in Nigeria. International Journal of Sociology and Anthropology, 1(1), 1-5.

Alo, O. A., \& Akinde, I. S. (2010). Premarital sexual activities in an urban society of Southwest-Nigeria. Journal of Medical Humanities and Social Studies of Science and Technology, 2, 1-16.

Alo, O. A. (2008). Socioeconomic determinants of unintended pregnancies among Yoruba women of Southwest Nigeria. International Journal of Sustainable Development, 1, 145-154.

Amato, P. R., \& Hohmann-Marriott, B. (2007). A Comparison of High- and Low-Distress Marriages That End in Divorce. Journal of Marriage and Family, 69(3), 621-638. http://dx.doi.org/10.1111/j.1741-3737.2007.00396.x

Booth, A., \& Johnson, D. (1988). Premarital cohabitation and marital success. Journal of Family Issues, 9 , 255-272. http://dx.doi.org/10.1177/019251388009002007

Clarke, C. J. (1947). Dating, engagement and marriage: How to find a mate the Godly way. Christian Courtship, London. Retrieved from http://www.abcog.org/court.htm

Cohan, C. L., \& Kleinbaum, S. (2002). Toward a greater understanding of the cohabitation effect: Premarital cohabitation and marital communication. Journal of Marriage and the Family, 64, 180-192. http://dx.doi.org/10.1111/j.1741-3737.2002.00180.x

Conger, R., Elder, G., Lorenz, F., Conger, K., Simons, R., Whitbeck, L., Huck, S., \& Melby, J. (1990). Linking economic hardship to marital quality and instability. Journal of Marriage and the Family, 52, 643-656. http://dx.doi.org/10.2307/352931

Ebony. (2000). Ten things you must know before you say 'I do', 55(10), 124-128. Aug 2000 ISSN 0012-9011, Johnson Publishing Company.

Erikson, E. H. (1968). Identity, Youth, and Crisis. New York, London.

Famuyide, E. O., \& Olunlade, R. O. (2001). Prevalence of teenage pregnancy among urban children in Ogun State. Nigerian Journal of Applied Psychology, 6, 31-38.

Finer, L. B. (2007). Trends in premarital sex in the United States, 1954-2003. Public Health Reports, 112(6), 29-36.

Henshaw, S. K., \& Kost, K. (1996). Abortion Patients in 1994-1995: Characteristics and Contraceptive Use. Family Planning Perspectives, 28, 140-147. http://dx.doi.org/10.2307/2136189

Ikpe, E. B. (2004). Understanding human sexuality seminar series. 2. Human sexuality in Nigeria: A historical perspective. Africa regional sexuality resource centre.

Inyang, M. P. (2007). Educating young people against risky sexual behaviours. In: Nwazuoke et al. (Eds.), Education for Social Transformation ( pp. 290-300), Ibadan: University Press.

Lewis, R., \& Spanier, G. B. (1979). Theorizing about the quality and stability of marriage. In: W. R. Burr, R. Hill, F. I. Nye \& I. L. Reiss (Eds.), Contemporary theories about the family (pp. 268-294). New York: Free Press.

National Population Commission (2000). Nigeria Demographic and Health Survey. Abuja.

Ogunniyi, S. O., Dare, F. O., Makinde, O. O., Ogunniyi, F. A., \& Ariyo, F. A. (1991). Pregnancy in teenagers in Ile-Ife, Nigeria-problems and perinatal outcome. Journal of Obstetrics and Gynecology, 11, 182-185. http://dx.doi.org/10.3109/01443619109013556

Okpani, A. O. U., Ikimalo, J., John, C. T., \& Briggs, N. D. (1995). Teenage pregnancy. Tropical Journal of Obstetrics and Gynaecology, 12 (Suppl. 1), 34-36. 
Oloko, B. A., \& Omoboye, A. O. (1993). Sexual Networking Among Some Lagos State Adolescent Yoruba Students. Health Transition Review, 3, 151-157. Retrieved from http://hdl.handle.net/1885/41172

Rena, R. (2006). Premarital sex - lessons from American experience, Ilorin (Nigeria). The Nigerian Journal of Guidance and Counseling, 11, 134-145. Retrieved from http://mpra.ub.uni-muenchen.de/12625/

Teachman, J. (2003). Premarital sex, premarital cohabitation, and the risk of subsequent marital dissolution among women. Journal of Marriage and Family, 65(2), 444-455. http://dx.doi.org/10.1111/j.1741-3737.2003.00444.x

Treas, J., \& Giesen, D. (2000). Sexual infidelity among married and cohabiting Americans. Journal of Marriage and the Family, 62, 48-60. http://dx.doi.org/10.1111/j.1741-3737.2000.00048.x

Vondey, W. (2010). Extra-marital Sex: Marriage's Greatest Enemy. Post on renewal dynamics Official Blog, Regent University of Divinity and centre for renewal studies. May 10th, 2010.

Voydanoff, P. (1990). Economic distress and family relations: A review of the eighties. Journal of Marriage and the Family, 52, 1099-1115. http://dx.doi.org/10.2307/353321

White, R., Cleland, J., \& Carael, M. (2000). Links between premarital sexual behaviour and extramarital intercourse: $\quad$ A multi-site analysis. http://dx.doi.org/10.1097/00002030-200010200-00013

WHO. (2001). Sexual relations among young people in developing countries: evidence from WHO case studies. WHO/RHR/01.8 Brown, A., Jejeebhoy, S. J., Shah, I., \& Yount, K. M. (Eds.). 